\title{
Oral Phase Dysphagia, the First Manifestation of Systemic Amyloidosis Associated with Multiple Myeloma
}

\author{
Ki Jong Hyun ${ }^{1}$, Sung Hoon Kim ${ }^{1}$, Lucia Kim², and Ji Won Kim ${ }^{1} \mathbb{D}$ \\ ${ }^{1}$ Departments of Otorhinolaryngology-Head and Neck Surgery, ${ }^{2}$ Pathology, Inha University College of Medicine, Incheon, Korea
}

구강기 연하곤란을 첫 증상으로 보인 다발성 골수종 관련 전신성 아밀로이드증 1 예

현기종 ${ }^{1} \cdot$ 김성훈 $^{1} \cdot$ 김루시아 ${ }^{2} \cdot$ 김지원 ${ }^{1}$

인하대학교 의과대학 이비인후과학교실, ${ }^{1}{ }^{\text {병리학교실 }}{ }^{2}$

\author{
Received May 14, 2020 \\ Revised July 9,2020 \\ Accepted August 12, 2020 \\ Address for correspondence \\ Ji Won Kim, MD, PhD \\ Department of Otorhinolaryngology- \\ Head and Neck Surgery, \\ Inha University College of Medicine, \\ 27 Inhang-ro, Jung-gu, \\ Incheon 22332, Korea \\ Tel $+82-32-890-3028$ \\ Fax $+82-32-890-3580$
}

E-mail hopefuljw@gmail.com

\begin{abstract}
Amyloidosis is a disease in which abnormal proteins called amyloid accumulates in various tissues. In the head and neck area, the larynx is the most common site with the rare involvement of the tongue, causing symptoms of macroglossia. Most of amyloid light-chain (AL) amyloidosis are systemic amyloidosis accompanied with multiple myeloma (MM), where the involvement of tongue can be often observed. We report a case of AL amyloidosis with MM, initially with symptoms of dysarthria and dysphagia without macroglossia, but gradually over the years, macroglossia and high tongue stiffness were observed.
\end{abstract}

Korean J Otorhinolaryngol-Head Neck Surg 2021;64(8):576-9

Key Words Amyloidosis - Dysarthria - Dysphagia - Multiple myeloma.

\section{서 론}

아밀로이드증은 아밀로이드라고 불리는 비정상 단백질이 다양한 조직에 축적되어 기능적인 장애를 동반하는 질환이 다. ${ }^{1)}$ 이중 형질 세포의 증식에 의해 수가 증가한 경쇄(light chain)가 아밀로이드로 작용하여 조직에 침범하는 형태를 아 밀로이드 경쇄 아밀로이드증(amyloid light-chain amyloidosis)라고 하며, ${ }^{2)}$ 다발성 골수종이 흔하게 동반된다. ${ }^{3)}$ 여러 장 기에 침입하는 경우 전신성 아밀로이드증(systemic amyloidosis)이라고 하며, 주로 침범하는 장기는 신장과 심장이다. 매우 드물게 혀에도 침범하여 대설증(macroglossia)과 구강 기 연하곤란, 발음장애 증상을 보일 수 있다. 아밀로이드와 관련된 혀의 증상들은 대부분 전신성 아밀로이드증에 이차 적으로 나타난다. ${ }^{4}$ 본 증례는 연하곤란, 발음장애 증상을 먼

This is an Open Access article distributed under the terms of the Creative Commons Attribution Non-Commercial License (https://creativecommons.org/licenses/by-nc/4.0) which permits unrestricted non-commercial use, distribution, and reproduction in any medium, provided the original work is properly cited.
저 보였다가 점진적으로 혀가 굳고 움직임이 감소하는 증상 이 나타나 조직검사를 통해 경쇄 아밀로이드증으로 진단받은 증례로서, 대설증이 아닌 구강기 연하곤란과 발음장애를 첫 증상으로 발현한 다발성 골수종을 동반한 경쇄 아밀로이드 증 증례는 현재까지 문헌상 보고되지 않아 이를 보고하고자 한다.

\section{증 례}

66세 남자 환자로, 2017년 6월 발음 장애와 연하곤란을 주 소로 본원 외래 내원하였다. 신체 진찰상 혀의 움직임은 감소 되었으나 혀 끝이 입천장을 향해 복면(ventral surface)에서 배면(dorsal side)으로 굽히기는 가능하였다(Fig. 1A). 연하곤 란의 원인 감별을 위하여 혈액검사 및 영상검사를 진행하였 으나 특이 소견은 관찰되지 않았다. 증상 조절을 위한 보존적 인 치료를 진행하였으나 혀가 두꺼워지고 움직임이 감소하여 발음장애와 연하곤란 증상은 심화되었다. 이후 2019년 7월 

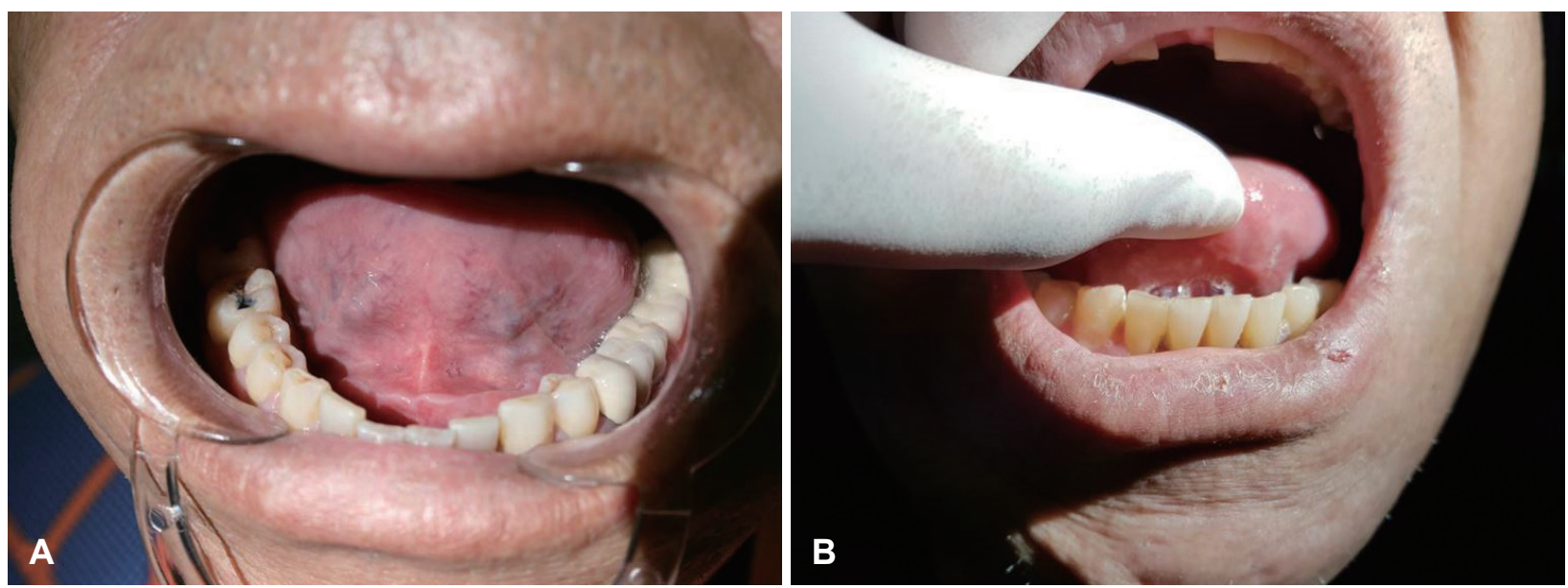

Fig. 1. Tongue mobility. In the early phase of the disease, the motion of tongue folding to superior side is possible (A). In the late phase, tongue is too hard to fold $(B)$.

점진적으로 심화되는 연하곤란 증상에 대해 타병원에서 비 디오 투시 연하검사를 시행하였고 유의한 구강기 연하곤란 소견이 관찰되었다. 2019년 10월 연하곤란과 발음장애에 대한 치료계획을 세우기 위해 본원 외래 재내원하였다. 시행한 신 체 진찰에서 혀는 2017년과 비교하여 더 건조하고 딱딱하였 고, 굽히기 및 내밀기가 불가능하였다(Fig. 1B). 시행한 자기공 명영상검사에서 혀의 비대소견 외 특이소견은 없었다(Fig. 2). 진단을 위해 혀의 우측 바깥쪽에서 $0.5 \mathrm{~cm}$ 검체를 채취하여 조직검사를 시행하였고, hematoxylin and eosin 염색에서 혈관주위와 사이질에 분홍색 물질이 관찰되고 무정형의 호 산성 물질이 관찰되어 아밀로이드 침착이 의심되었으며(Fig. $3 \mathrm{~A}$ ), Congo-red 염색에서 녹색의 이중 굴절(apple green birefringence)을 확인하였다(Fig. 3B). 혈액과 소변에서 시행 한 면역 고정 전기 영동(immunofixation electrophoresis)에 서 람다사슬밴드(lambda chain band)가 관찰되었다. 위 소 견으로 혀와 신장에 침범한 아밀로이드증으로 진단할 수 있 었다. 혈액검사에서 적혈구색소는 9.5(13.1 17.5) g/dL로 감소 되었고, 칼슘은 $14.6(8.6 ~ 10.7) \mathrm{mg} / \mathrm{dL}$ 로 증가, 크레아티닌은 2.42(0.50 1.20) mg/dL로 증가되어 있었다. 빈혈, 고칼슘혈증, 급성신부전으로 다발성 골수종(multiple myeloma)이 의심되 어 본원 혈액종양내과에서 골수검사를 시행하였으며, 형질 세포(plasma cell)의 증가, 람다사슬(lambda chain) 양성 소 견으로 다발성 골수종 소견과 조직검사 결과에 따라 경쇄 아 밀로이드증을 확진할 수 있었다. 환자는 경쇄 아밀로이드증과 다발성 골수종에 대하여 새로운 항형질세포 제제(novel antiplasma cell agents)로 치료 중이며, 치료 시작 후 혀 증상과 관련된 연하곤란, 발음장애 증상은 더 악화되지 않고 있다.

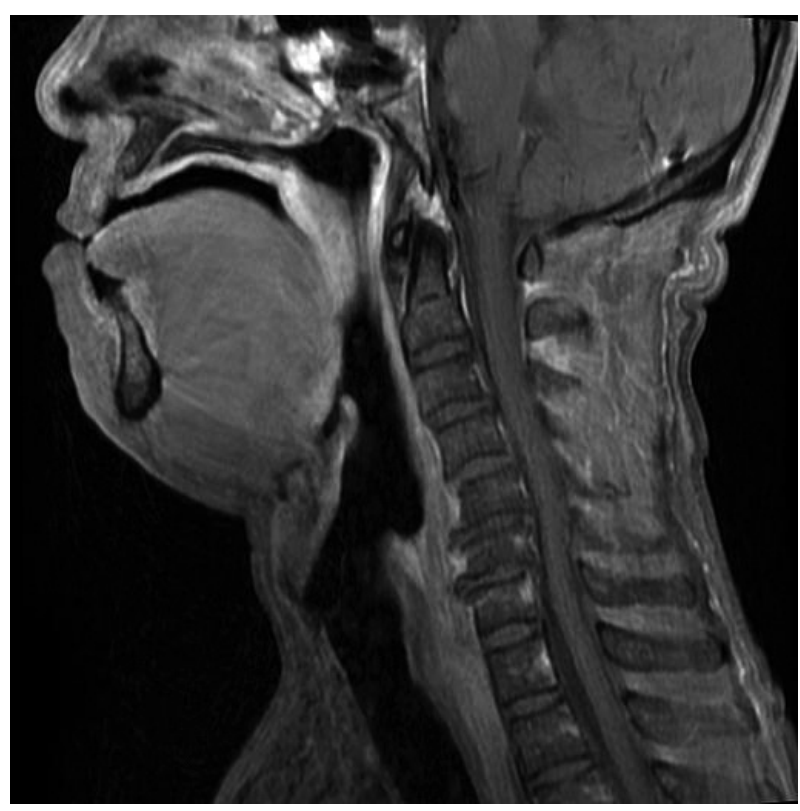

Fig. 2. Sagittal T1 weighted image shows hypertrophy of tongue and floor of mouth.

\section{고 찰}

아밀로이드증은 아밀로이드라고 불리는 비수용성 단백질 이 세포밖에 축적되는 질환으로, 다양한 조직에 축적되어 다 양한 증상이 나타날 수 있다.5) 아밀로이드가 이비인후과 영 역에 침범하는 것은 드물며 주로 침범하는 부위는 후두이고 그 외 기관, 기관지, 혀, 갑상선, 침샘, 인두 등을 침범할 수 있 다.) 아밀로이드증은 발현된 증상의 범위에 따라 전신성 아 밀로이드증과 국소 아밀로이드증으로 분류한다. 전신성 아밀 로이드증은 침범한 기관에 따라 다양한 증상을 보이며 혀에 침범하면 대설증, 연하장애 증상을 발생시킬 수 있다. ${ }^{6}$ 혀를 침범하는 전신성 아밀로이드증은 다발성 골수종을 동반하는 


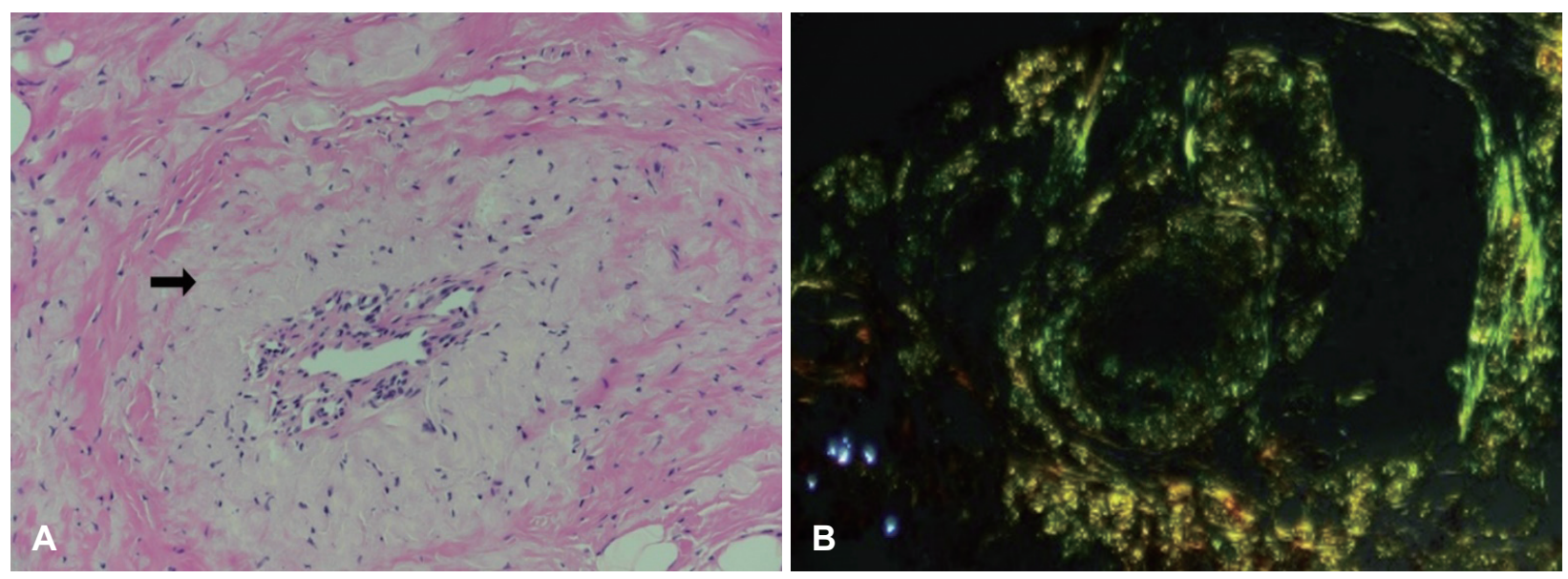

Fig. 3. Pathologic findings show characteristic eosinophilic amorphous extracellular material infiltration into muscular tissue (arrow) (hematoxylin and eosin stain, $\times 200)($ A). Pathologic findings show distinctive apple green birefringence which is a feature of amyloidosis (Congo-red stain, $\times 200)(B)$.

경우가 대부분이며 이를 경쇄 아밀로이드증이라 하고, 혀를 침범하여 대설증 증상이 나타나는 경우는 $10 \%$ 정도로 보고 되나 연하곤란 증상이 나타나는 경우는 흔치 않다.7) 다발성 골수종은 단일클론 면역 글로불린을 분비하는 혈장세포의 악성 질환이다. ${ }^{8)}$ 신부전, 빈혈, 골병변, 고칼슘혈증의 4 가지 대표적인 임상증상을 보이나 아밀로이드증 동반없이 연하곤 란이 발생하는 경우는 없다. ${ }^{9}$

경쇄 아밀로이드증은 채취된 조직에서 Congo-red 염색 후 녹색의 이중 굴절이 보이면 진단한다. ${ }^{10}$ 혈액과 소변에서 면역 고정 전기 영동법을 시행하여 경쇄를 확인하는 것과 혈액 내 유리형 경쇄(free light chain)의 증가를 확인하는 것도 진단 에 도움이 된다. ${ }^{10)}$ 치료는 아밀로이드 전구체 단백질을 감소 시키고 기관에서 아밀로이드 원 섬유 침착을 방지하는 것이 다. ${ }^{10)}$ 현재 근치적인 치료 사용되는 것은 고용량 정맥 melphalan 투여 후 조혈모세포 이식으로 다발성 골수종에 대한 치료이다. ${ }^{11)}$ 일반적으로 환자는 6 15개월의 생존율을 보이며, 신부전, 심부전, 또는 자율신경병증으로 사망한다. ${ }^{12)}$ 치료 시 기에 따라 예후에 차이가 있어 조기에 진단하고 치료하는 것 이 중요하다. 하지만 구강기 연하곤란과 발음장애, 대설증 등 혀에 국한된 증상만으로 전신성 아밀로이드를 의심하는 것 은 쉽지 않다. 현재까지 보고된 케이스가 매우 드물며, 결핵, 림프관종, 갑상선저하증, 말단비대증, 혀의 악성종양, 갑상선 기능저하증, 그리고 엽산 및 비타민 B12 결핍증 등과 영상검 사 및 혈액검사를 통해 감별해야 한다. ${ }^{13,14)}$

본 증례에서 발음 장애와 연하 곤란이 수년에 걸쳐 점진적 으로 발전한 환자의 혀에 대해 시행한 조직검사로 전신성 아 밀로이드증이 진단된 증례에 대해서 보고하였다. 증상 초기 시행한 검사에서 특이소견은 없었으나 수년 뒤, 빈혈, 고칼슘 혈증, 급성 신부전을 보이는 다발성 골수종이 발생하였고, 신
장과 혀를 침범한 전신성 경쇄 아밀로이드증도 확인되었다. 경쇄 아밀로이드증 치료 시 혈액학적인 관해는 가능하나 이 미 조직에 침범한 아밀로이드를 제거하는 것은 불가능하다. 이러한 이유로 경쇄 아밀로이드증을 완치하는 것은 어려우나 조기진단을 통해 치료를 일찍 시작하는 것은 환자의 생존율 을 높인다. ${ }^{15)}$ 혀 증상으로부터 아밀로이드증이 진단된 증례는 드물어서 혀조직을 침범한 경쇄 아밀로이드증은 진단과 치료 시기가 늦어져 환자의 예후에 부정적 영향을 미칠 수 있다. 대설증을 주소로 아밀로이드증 및 다발성 골수종을 진단받 았던 사례는 보고된 바 있으나, ${ }^{16)}$ 구강기 연하곤란 증상으로 다발성 골수종을 동반한 경쇄 아밀로이드증으로 진단받은 증례는 현재까지 문헌상 보고되지 않았다. 따라서 구강기의 연하곤란 및 발음장애를 보이는 환자에서 혀에 대한 조기 조 직검사를 통해 아밀로이드 침범 여부를 조기 확인하는 것이 필요하다고 할 수 있겠다.

구강기 연하곤란과 발음장애를 보이는 환자에서 아밀로이 드증 및 다발성 골수종을 감별할 필요가 있으며, 조직검사를 통하여 조기에 진단을 내리고 치료를 시작한다면 아밀로이드 가 다른 기관으로 침범하는 것을 예방하여 예후에 긍정적인 영향을 미칠 수 있다.

\section{Acknowledgments}

This research was supported by Inha University research grant.

\section{Author Contribution}

Data curation: Ki Jong Hyun. Formal analysis: Ki Jong Hyun. Investigation: Lucia Kim. Project administration: Ji Won Kim. Supervision: Sung Hoon Kim. Visualization: Lucia Kim. Writing-original draft: Ki Jong Hyun. Writing — review \& editing: Ji Won Kim.

\section{ORCID}

Ji Won Kim 


\section{REFERENCES}

1) Milani P, Palladini G, Merlini G. New concepts in the treatment and diagnosis of amyloidosis. Expert Rev Hematol 2018;11(2):11727.

2) Haraguchi H, Ohashi K, Yamada M, Hasegawa M, Maeda S, Komatsuzaki A. Primary localized nodular tongue amyloidosis associated with Sjögren's syndrome. ORL J Otorhinolaryngol Relat Spec 1997;59(1):60-3.

3) Kyle RA, Bayrd ED. Amyloidosis: Review of 236 cases. Medicine (Baltimore) 1975;54(4):271-99.

4) Babburi S, Ramya B, Subramanyam Rv, Aparma V, Srivastava G. Amyloidosis of the tongue-report of a rare case. J Clin Diagn Res 2013;7(12):3094-5.

5) Matsuo FS, Barbosa de Paulo LF, Servato JP, de Faria PR, Cardoso SV, Loyola AM. Involvement of oral tissues by AL amyloidosis: A literature review and report of eight new cases. Clin Oral Investig 2016;20(8):1913-20

6) Send T, Spiegel JL, Schade G, Pantelis A, Olthoff A, Bootz F, et al. Amyloidosis of the upper aerodigestive tract: Management of a rare disease and review of the literature. Dysphagia 2019;34(2):179-91.

7) Gonzalez J, Wahab A, Kesari K. Dysphagia unveiling systemic immunoglobulin light-chain amyloidosis with multiple myeloma. BMJ Case Rep 2018;2018:bcr2018226331.

8) Falk RH, Comenzo RL, Skinner M. The systemic amyloidoses. N Engl J Med 1997;337(13):898-909.

9) International Myeloma Working Group. Criteria for the classification of monoclonal gammopathies, multiple myeloma and related disorders: A report of the International Myeloma Working Group. Br J Haematol 2003;121(5):749-57.

10) Stevens FJ, Myatt EA, Chang CH, Westholm FA, Eulitz M, Weiss DT, et al. A molecular model for self-assembly of amyloid fibrils: Immunoglobulin light chains. Biochemistry 1995;34(34):10697702.

11) Comenzo RL, Vosburgh E, Simms RW, Bergethon P, Sarnacki D, Finn K, et al. Dose-intensive melphalan with blood stem cell support for the treatment of AL amyloidosis: One-year follow-up in five patients. Blood 1996;88(7):2801-6.

12) Xavier SD, Bussoloti IF, Müller H. Macroglossia secondary to systemic amyloidosis: Case report and literature review. Ear Nose Throat J 2005;84(6):358-61.

13) Fahrner KS, Black CC, Gosselin BJ. Localized amyloidosis of the tongue: A review. Am J Otolaryngol 2004;25(3):186-9.

14) Costa JHSM, de Paula AB, de Oliveira Campos L, de Paula RB, Gotardelo DR. Macroglossia and periorbital ecchymoses in a patient with systemic amyloidosis: A case report. Int J Case Rep Images 2015;6(6):343-7.

15) Muchtar E, Gertz MA, Kumar SK, Lacy MQ, Dingli D, Buadi FK, et al. Improved outcomes for newly diagnosed AL amyloidosis between 2000 and 2014: Cracking the glass ceiling of early death. Blood 2017;129(15):2111-9.

16) Maturana-Ramírez A, Ortega AV, Labbé FC, de Moraes Ê, AitkenSaavedra JP. Macroglossia, the first manifestation of systemic amyloidosis associated with multiple myeloma: Case report. J Stomatol Oral Maxillofac Surg 2018;119(6):514-7. 